\title{
Influence of Environmental Concerns and Moral Obligation on Purchase Intention: Evidence from Cambodia
}

\author{
Ying-Kai Liao
}

Program of International Business, Nanhua University, Chiayi County, Taiwan

Wann-Yih Wu

Program of International Business, Nanhua University, Chiayi County, Taiwan

Thi-That Pham*

Department of Business Administration, Nanhua University, Chiayi County, Taiwan

\section{Hourt Sengheang}

HGB Group Co. Ltd, Phnom Penh, Cambodia

*Corresponding author: thatphamlded@gmail.com

\section{Abstract}

Environmental issues and sustainability have attracted considerable attention. The public have been asked to change their conventional consumption patterns and purchase behaviours. This study expanded the theoretical base of green purchasing by extending the theory of planned behaviour (TPB) and essays a comprehensive research framework to identify the antecedents and mediators of green purchase intention (GPI). Smart PLS version 3.2.8 was employed to test the theoretical framework against 314 observations of customers who had bought green products in Phnom Penh, Cambodia. The current study extended the framework of the TPB model, in which perceived moral obligation (PMO) is introduced as an antecedent of attitudes towards green products, subjective norms ( $\mathrm{SN}$ ), and perceived behavioural control (PBC) vis-a-vis GPI. The findings reveal that environmental awareness and environmental concerns have a significant and positive influence on SN, PMO, and PBC. They also show that consumers' PMO has a positive and significant impact on customers' perceived value, including perceived environmental value and perceived environmental image. Furthermore, SN, PMO, PBC, and customers' perceived value have a significant effect on attitudes towards green products. Both customer's attitudes and perceived value have a positive effect on GPI. Theoretical and managerial implications are provided.

Keywords: Environmental concerns, Environmental awareness, Perceived moral obligation, Perceived behavioural control, Attitude towards green products, Green purchase intention. 


\section{Introduction}

The consumption of products and services has increased tremendously around the world, depleting natural resources and causing severe harm to the environment, for instance through global warming, air, water, and land pollution, and the accumulation of waste. These concerns have forced humanity to focus on the issue of environmentally responsible consumption. White et al. (2019) argued that green consumption should be considered as a means of addressing environmental concerns. Moreover, sustainability concerns have prompted many countries to recognize the importance of protecting Earth by reducing the harmful impact of business activities on the environment. Within this context, it is very important for firms to produce and supply green products to customers. Consumers can also prevent or mitigate environmental damage by purchasing green products. However, there is little evidence that green purchases are growing in popularity. Despite expressions of concern and positive attitudes to sustainability and green items, the market share of the remains limited to between $1 \%$ and 3\% (Bray et al., 2011).

Even though consumers ostensibly worry about the deterioration of the natural environment, their green purchasing behaviour is still at a low level (Witek, 2019). This discrepancy between attitudes and purchasing behaviours has been dubbed the "green purchasing inconsistency" (Witek, 2019). Therefore, it is important to identify the motivations behind the GPI and its relationship to green purchase behaviour. In the present study, we focused on examining the GPI rather than behaviour because (i) GPI represents consumers' willingness to engage in green consumption and because, (ii) intentions capture the motivational elements that affect a consumer's green purchase behaviour (Ramayah et al., 2012). Furthermore, there is significant evidence that behavioural intention influences subsequent preference judgments and behaviour (Morwitz and Fitzsimons, 2004). Therefore, this study uses behavioural intention as a construct for its outcome.

The theory of planned behaviour (TPB) is a reasoned action framework developed by Ajzen (1985) in order to define, predict, and change consumer behaviours. According to the TPB, actual behaviour is determined by intention. Intention, in turn, is determined jointly by an individual's attitude towards the actuation of the behaviour, the perceived social influence of referent others (subjective norm, SN), and perceived behavioural control (PBC) over the behaviour. These three determinants of intention have their roots in individual beliefs (Ajzen, 2012). The TPB is widely used, and it has been applied in a variety of contexts (Moons and De Pelsmacker, 2012), including environment-related behaviour (Zeinab, 2021). Besides, most previous studies have used TPB to evaluate GPI (e.g., Buschmann et al., 2020; Aboelmaged, 2020). Therefore, this study employs the TPB to explain its hypotheses and to test its framework. Furthermore, Taufique et al. (2016) indicated that if consumers lack awareness and knowledge of green products, an attitude-behaviour gap will open between their environmental concerns and their purchasing behaviours. This gap may have a substantial impact on purchase intention and could predict sustainable consumption behaviour. Hence, environmental concern (EC) and environmental awareness (EA) are considered equally significant determinants of the decision to purchase green products (Scott and Vigar-Ellis, 2014). On the basis of these arguments, this study integrates the constructs of EC and EA into the theoretical framework of TPB as antecedents of GPI. 
Furthermore, personal norms and feelings of moral obligation are critical to encouraging individual pro-environment behaviours (Shi et al., 2017). Similarly, the social cognitive theory literature identifies a strong association between moral reasoning and altruistic behaviour. According to that theory, individuals tend to perform moral actions in line with their moral standards by employing self-regulatory mechanisms (Bandura, 2002). The higher an individual's level of moral reasoning, the more likely they are to behave altruistically. Very few studies have integrated value, EC, EA, and morality into a comprehensive framework for GPI. To the best of the authors' knowledge, none have combined these constructs to predict customers' GPIs. This study intends to close these gaps by identifying the antecedents, mediators, and consequences of GPI. Finally, Paul et al. (2016) suggested that consumers from developed countries are more concerned about the environment than consumers from other countries. A significant number of recent studies have focused on proenvironmental behaviours in developed countries (Gu et al., 2020; Varah et al., 2020). Few studies of developing countries have been carried out. In Cambodia, research on environmental issues and green purchasing intention is nascent, and thus less advanced than in other developing countries (Nuttavuthisit and Thøgersen, 2017). The present study fills this gap by conducting a survey in Cambodia. More specifically, the objectives of this study are: (1) to investigate the effects of EA, and EC on SN, perceived moral obligation (PMO), and PBC; (2) to investigate the effects of EA, and EC on ATT and green customer value (GCV); (3) to determine the influence of ATT and GCV on GPI; and (4) to investigate the roles of SN, PMO, PBC, ATT, and GCV in mediation between EA, EC, and GPI.

\section{Theoretical Background}

\section{Theory of Planned Behaviour (TPB)}

Ajzen's (1991) TPB explains behavioural intentions by reference to three concepts: attitude, SN, and PBC. The theory suggests that an individual's prior attitude towards GPI and its influence, that is, the extent to which the individual attempts to change the way they purchase and consume, is related to attitudes and beliefs (Lin et al., 2015). The fundamental tenet of the TPB is that a particular behaviour is likely to occur when individuals exhibit a positive attitude towards it, when they feel that their social circles approve or support it, and when they believe themselves capable of adopting it. Attitudes are the last element of the overall evaluation, and they are endowed with an emotional charge for or against a social object, which prejudges action in line with the cognitions and emotions that attach to that object (Rodríguez-Barreiro et al., 2013). SN indicates how individuals perceive social responsibility when they purchase green products and how they value the social perceptions of others (Barber et al., 2014). PBC refers to the degree of control that individuals perceive themselves to possess over the performance of a behaviour (Kang et al., 2006). Empirical research indicates that the TPB can explain pro-environmental actions such as Varah et al. (2020), and Nimri et al. (2020). In the current study, the TPB was adopted to explain the purchase intention. Furthermore, this study followed the findings of Kim et al. (2013), who emphasized that attitude is one of the critical factors that may mediate the effect of SN and PBC on consumer behavior intention. 


\section{Value-Belief-Norm Theory (VBN)}

Stern (2000) and Bockarjova and Steg (2014) proposed the use of VBN theory to explain the manifestation of pro-environmental behaviour. The authors also suggested that the strength of normative goals depends on environmental values and situational factors (e.g., biosphere values, situational cues, behavioural costs) that influence the accessibility of sustainability values. In addition, the VBN theory has been used to predict pro-environmental behaviour in Taiwan, enhancing its claim to intercultural validity (Chen, 2014). The VBN theory is currently the most common method for exploring the determinants of environmental behaviour. As noted earlier, researchers can apply VBN theory to study EA, EC, and ATT as well as their relationship with GPI.

\section{Environmental Awareness and Environmental Concern}

Previous research has highlighted the connection between EA, which is the extent to which customers are worried about threats to the environment (Lee et al., 2014), and pro-environmental behaviours. EC captures the degree to which people are conscious of environmental problems and their willingness to explain them (Ari \& Yilma, 2017). Aman et al. (2012) indicated that consumers with a higher level of concern for the environment might be enthusiastic about green products, and EC is often cited as a strong motivator for purchasing them (Yue et al., 2020). EC implies a sense of responsibility for protecting the environment. Combined with emotions at the individual level, it may encourage consumers' involvement in pro-environmental activities (Prakash \& Pathak, 2017). Yang et al. (2020) indicated that consumers who exhibit high levels of environmental awareness are more likely to engage in such activities. Therefore, we predict that:

\section{H1 EA has a positive effect on EC.}

\section{Environmental Concern, Environmental Awareness, Subjective Norm, Perceived Moral Obligation, and Perceived Behavioural Control}

Ishaswini and Datta (2011) reported that EC has a positive effect on green purchase behaviour in India. EC and brand knowledge are likely to be two of the critical variables that influence consumers' GPI (Wheeler et al., 2013). Chan (2001) indicate that EA stimulates pro-environmental behaviour, and a number of studies have found evidence of its significant impact on pro-environmental behaviour (Pinto et al., 2011). According to Stern (2000), value-belief-norm (VBN) theory argues that values may affect SN. The argument is driven by the propositions that (a) behaviour stems from the acceptance of certain values, (b) things important to those values are under threat, and (c) the person's actions can help alleviate the threat and restore the values. The VBN theory proposes a causal nexus between values, beliefs, awareness of consequences, the ascription of responsibility, SN and pro-environmental behaviours. Following Wang et al. (2016), it appears likely that respondents' SN, PMO, and PBC are impacted by EA and EC. Thus, we propose that:

H2 EC has a positive effect on (a) SN, (b) PMO, and (c) PBC.

H3 EA has a positive effect on (a) SN, (b) PMO, and (c) PBC. 


\section{Subjective Norms, Attitude towards Green Products, Green Customer Value}

The TPB indicates that attitudes, SN, and PBC are key factors that influence consumers' intentions and purchasing behaviours (Vaishali \& Anuradha, 2020). An SN is described as social pressure or effect that empowers an individual to implement a behaviour (Sreen et al., 2018). In particular, individual behaviour is conditioned by the approval and disapproval of other individuals (Choi et al., 2015). Consumers, when in doubt about a specific behaviour, might look for support from others (Jiang et al., 2019). The "others" in question may be friends, relatives, family members, peer groups, and other reference groups. It seems that SN may affect customer's ATT, which drive actual behaviour.

Perceived value is defined as a consumer's overall evaluation of the net benefits of a product or service (Patterson \& Spreng, 1997). The concept of perceived value has been widely employed to illustrate a customer's assessment of products, services, and market relationships. According to Hänninena \& Karjaluoto (2017), the key feature of perceived value is its relativity, that is, perceived value is assessed by reference to alternative or competing offerings. It explains how customers choose certain products or suppliers over others. Perceived value could be a crucial determinant of the durability of long-term customer relationships, and it has a significant effect on purchase intentions. As a driver of customers' perceived value, environmental image represents the outcome of the supplier's intimations of sustainability. By creating a positive environmental image, a supplier complies with stakeholder demands and gains a minimal level of environmental legitimacy (Junquera et al., 2012). In this way, the supplier may differentiate themselves from their competitors. Customers' perceptions of the value of environmental efforts affects business relationships because the concept has both financial and non-financial aspects, thus tapping into the interplay between economic and environmental benefits in value assessment (Reuter et al., 2012). Therefore:

H4 SN has a significant effect on (a) ATT and (b) GCV.

\section{Perceived Moral Obligation, Attitude towards Green Products, Green Customer Value}

When a person participates in a specific act while feeling proud or guilty, this is referred to as perceived moral obligation ( $\mathrm{Fu}$ et al., 2018). Ajzen (1991) defined moral obligation as the obligation to perform or refuse to perform a specific behavior. Similarly, Shaw et al. (2015) stated that those consumers who are ethical and demonstrate a moral obligation by caring for the environment or a community are sensitive to ecological issues. According to Spielmann (2020), 70\% of consumers believe it is their responsibility to engage in greener behaviors because doing so allows them to participate in more moral acts. Driven by a sense of individual duty and commitment, a customer will exhibit eagerness and an intention to perform a specific activity. PMO alludes to whether a person feels an obligation to perform an act in an ethical setting (Beck \& Ajzen, 1991). PMO is combined with the ethical commitments of TPB to determine an individual's enthusiasm for preserving vitality, and reducing carbon emissions (Chen, 2016). Mäkiniemi \& Vainio (2013) demonstrated that ethical recognition can boost the determination to make climate-friendly nutritional choices. Hence, we propose that:

H5 PMO has a significant effect on (a) ATT and (b) GCV. 


\section{Perceived Behavioural Control, Attitude towards Green Products, Green Customer Value}

The individual's assessment of the difficulty of performing a behavior is defined as PBC. It is linked to the individual's belief in their ability to carry out the corresponding actions (Fishbein \& Ajzen, 2011). The primary barriers that prevent consumers from purchasing green products, according to Barbarossa and Pastore (2016), are cost and convenience. Similarly, some studies have found that time, cost, availability, and ignorance all work against GPI (Sreen et al., 2018). Green consumers must overcome these barriers in order to increase the customer perceived value of products (Barbarossa $\&$ Pastore, 2016). Perceived value in marketing is defined as customer assessment of costs and benefits of the purchase of a product or service. Customers initially tend to consume services which reduce costs or have earnings for them ( $\mathrm{Yu}$ et al., 2020). Hence, this study propose that PBC will effect on GCV. Thus:

H6 PBC has a significant effect on (a) ATT and (b) GCV.

\section{Green Customer Value and Attitude towards Green Products}

Judgments and actions reflect conflicting motivations. For example, personal interest may be pitted against the welfare of others. Environmental values do not translate into preferences and outcomes directly. Instead, decisions result from trade-offs between potentially conflicting values (Reuter et al., 2012). When it comes to brands and products, values and images can play a significant role in the consumer's decisionmaking process (Al-Gasawneh \& Al-Adamat, 2020). Value provides a starting point for understanding a consumer's behaviour within their culture (Li \& Cai, 2012). Value is interpreted by reference to cognitive and affective conditions that impact purchasing choices and brand selection (Gallarza et al., 2011). Both perspectives can be helpful in the identification of the product attributes that impact consumers' perceived value (Gershoff \& Frels, 2015). Therefore:

H7 A higher level of GCV relates positively to customers' ATT.

\section{Green Customer Value and Green Purchase Intention}

According to Blackwell et al. (2012), value provides a basis for understanding consumer behaviour within and across cultures. Consequently, values are inextricably linked to consumers' attitudes and affect their purchase behaviour (Li et al., 2012). Environmental image is a crucial driver of the environmental purchasing intentions of industrial customers (Björklund, 2011). Amoako et al. (2020) suggested that green value is more important than trust in the purchasing decisions of Ghanaian youths. Hamzah \& Tanwir (2020) demonstrate that perceived green value influences GPI for hybrid vehicles positively. Hence:

H8 Higher levels of perceived environmental value, and environmental image relates positively to GPI.

\section{Attitude towards Green Products and Green Purchase Intention}

According to various empirical studies, a positive attitude boosts intentions to buy green products (Michaelidou \& Hassan, 2010). One's attitude towards a behaviour depends on whether the individual assesses the behaviour in question favourably or 
unfavourably (Klöckner, 2013). In psychology, an attitude is a set of emotions, beliefs, and behaviours that concern a particular object, person, thing, or event. Joshi \& Rahman (2015) demonstrated that consumers who exhibit a favourable or positive attitude might experience a stronger sense of attachment to their purchasing decisions. Attitudes have a clear role in decisions to accept specific behaviours. Recently, it has been argued that, out of all TPB predictor constructs, attitude towards green products has the strongest direct influence on consumers' GPI (Liao et al., 2020). These fundamental relationships have also been validated and supported in the context of emerging Asian economies (Jaiswal \& Kant, 2018). Thus:

H9 ATT is positively associated with GPI.

\section{Research Design and Methodology}

\section{Research Framework}

The research model shown below was designed to test the hypotheses. EA and EC are the antecedents of SN, PMO, PBC, ATT, GCV, and GPI.

\section{Figure 1: The Theoretical Framework}

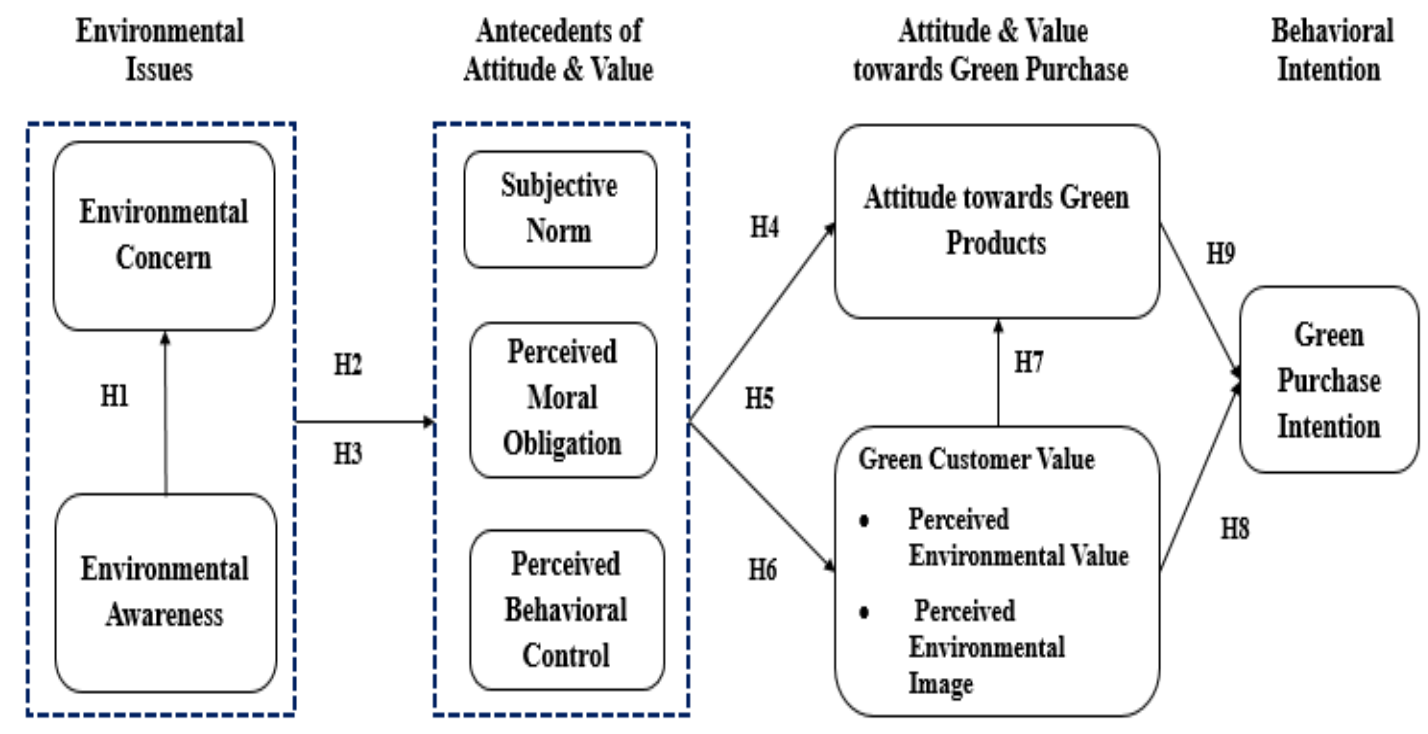

\section{Sample and Data Collection}

The questionnaire was administered to respondents who had made green purchases in Cambodia. Cross-sectional data were collected because they are widely used, inexpensive, quick, accurate, and efficient (Zikmund and Babin, 2010). The respondents were from Phnom Penh because it is the capital of Cambodia and it has the highest number of middle-income urban residents (World Bank, 2021). The selection of Phnom Penh allowed the researchers to economize on time and money as well as to improve the efficiency of questionnaire administration. A screening question about green purchasing experience was designed to filter respondents. In total, 420 
questionnaires were distributed, and a total of 339 valid responses were returned, with 25 eliminated because of missing data. Consequently, 314 questionnaires were analysed further. Out of the 314 respondents, $61.8 \%$ were male. The most common age bracket was $26-35(46.8 \%)$ followed by 25 and below (42.3\%). The majority of respondents $(56 \%)$ had undergraduate degrees. Many $(33.4 \%)$ held postgraduate qualifications, $9.2 \%$ did not hold a university degree, and $1.4 \%$ had $\mathrm{PhDs}$. The private sector accounted for $35.6 \%$ of respondents, and $32.5 \%$ were students. All respondents stated that they had purchased green products.

\section{Constructs Measurement}

Eight constructs were measured. The questionnaire items that covered EC were adapted from Aman et al. (2012; 6 items). The EA items were adapted from Carrete et al. (2012) and Kollmuss et al. (2002; 5 items). The ATT items were adapted from Ajzen (1991); and Ivancevich et al. (2010; 5 items). The SN items were adapted from Ross and Hahn (2019), Ajzen (1991), and Paul et al. (2016; 6 items). The PBC items were adapted from Ajzen (1991); and Zhou et al. (2013; 5 items). The PMO items were adapted from Beck and Ajzen (1991) and Leonard et al. (2004; 5 items). GCV items, including perceived environmental value, were adapted from Oskamp et al. (1991; 5 items), and perceived environmental image items were adapted from Appolloni et al. (2014), and Junquera et al. (2012; 5 items). The GPI items were adapted from Lai et al. (2016), Chan (2001), and Mostafa (2007; 7 items). All of the items were rated on a five-point Likert scale, from 1 ("strongly disagree") to 5 ("strongly agree").

\section{Data Analysis and Results}

\section{Measurement Model}

The consistency of the constructs and their convergent and discriminant validity were investigated through the measurement model. Construct reliability was inspected through Cronbach's alpha and composite reliability. Table 1 shows that Cronbach's alpha ranges from 0.802 to 0.920 and that composite reliability varies between 0.867 and 0.941. Both of these values exceed 0.70 (Hair et al., 2014), indicating that the measurements are reliable. In addition, the values of Dillon-Goldstein's rho were greater than 0.9 for all constructs. Convergent validity was tested by extracting factor item loads, composite reliability, and average variance (AVE). The analysis achieved convergent validity: factor loading, composite reliability, and AVE were greater than $0.60,0.70$, and 0.50 , respectively.

The common method variance (CMV) bias that may result from the adoption of a crosssectional design (Mackenzie and Podsakoff, 2012). Firstly, a Harmon one-factor test was adopted and loaded all variables into a principal component factor analysis (Podsakoff et al., 2003). The explained variance of the one-factor test is $37.48 \%$ in the unrotated solution, which is less than $50 \%$. Second, discriminant validity was tested by comparing the square root of the AVE with the Pearson correlations between constructs. All square roots of the AVE estimates, which are shown in Table 1, are greater than the corresponding inter-construct correlation coefficients. These results suggest that CMV is still at acceptable levels. The following sections present the additional tests that were carried out. 
Table 1: Factor Loadings and Reliability Statistics

\begin{tabular}{|c|c|c|c|c|c|c|}
\hline Constructs & Items & Loadings & $\begin{array}{c}\text { Cronbach's } \\
\operatorname{Alpha(\alpha )} \\
\end{array}$ & $\begin{array}{l}\text { Composite } \\
\text { Reliability }\end{array}$ & AVE & Rho-A \\
\hline & EA1 & 0.869 & & & & \\
\hline Environmental & EA2 & 0.914 & & & & \\
\hline \multirow{5}{*}{$\begin{array}{l}\text { Awareness } \\
\text { (EA) }\end{array}$} & EA3 & 0.828 & 0.915 & 0.923 & 0.767 & 0.932 \\
\hline & EA4 & 0.937 & & & & \\
\hline & EA5 & 0.831 & & & & \\
\hline & $\mathrm{EC} 1$ & Deleted & & & & \\
\hline & EC2 & 0.731 & & & & \\
\hline \multirow{6}{*}{$\begin{array}{l}\text { Environmental } \\
\text { Concern } \\
\text { (EC) }\end{array}$} & EC3 & 0.877 & & & & \\
\hline & EC4 & Deleted & 0.905 & 0.907 & 0.710 & 0.905 \\
\hline & EC5 & 0.844 & & & & \\
\hline & EC6 & 0.907 & & & & \\
\hline & SN1 & 0.730 & & & & \\
\hline & SN2 & 0.606 & & & & \\
\hline Subjective & SN3 & 0.737 & & & & \\
\hline \multirow[t]{3}{*}{ Norm (SN) } & SN4 & 0.807 & 0.803 & 0.878 & 0.648 & 0.840 \\
\hline & SN5 & 0.663 & & & & \\
\hline & SN6 & 0.810 & & & & \\
\hline \multirow{5}{*}{$\begin{array}{l}\text { Perceived } \\
\text { Moral } \\
\text { Obligation } \\
\text { (PMO) }\end{array}$} & PMO1 & 0.886 & & & & \\
\hline & PMO2 & 0.844 & & & & \\
\hline & PMO3 & 0.826 & 0.877 & 0.915 & 0.730 & 0.895 \\
\hline & PMO4 & 0.876 & & & & \\
\hline & PMO5 & Deleted & & & & \\
\hline \multirow{5}{*}{$\begin{array}{l}\text { Perceived } \\
\text { Behavioural } \\
\text { Control } \\
\text { (PBC) }\end{array}$} & PBC1 & 0.929 & & & & \\
\hline & PBC2 & 0.912 & & & & \\
\hline & PBC3 & 0.734 & 0.895 & 0.875 & 0.759 & 0.897 \\
\hline & PBC4 & 0.949 & & & & \\
\hline & PBC5 & 0.771 & & & & \\
\hline \multirow{5}{*}{$\begin{array}{c}\text { Attitude } \\
\text { towards Green } \\
\text { Products } \\
\text { (ATT) }\end{array}$} & ATT1 & 0.924 & & & & \\
\hline & ATT2 & 0.927 & & & & \\
\hline & ATT3 & 0.930 & 0.920 & 0.941 & 0.761 & 0.936 \\
\hline & ATT4 & 0.750 & & & & \\
\hline & ATT5 & 0.815 & & & & \\
\hline \multirow{5}{*}{$\begin{array}{c}\text { Perceived } \\
\text { Environmental } \\
\text { Value } \\
(\text { PEV) }\end{array}$} & PEV1 & 0.741 & & & & \\
\hline & PEV2 & 0.828 & & & & \\
\hline & PEV3 & 0.756 & 0.813 & 0.885 & 0.600 & 0.842 \\
\hline & PEV4 & 0.783 & & & & \\
\hline & PEV5 & 0.764 & & & & \\
\hline \multirow{5}{*}{$\begin{array}{l}\text { Perceived } \\
\text { Environmental } \\
\text { Image } \\
\text { (PEI) }\end{array}$} & PEI1 & 0.688 & & & & \\
\hline & PEI2 & 0.902 & & & & \\
\hline & PEI3 & 0.733 & 0.810 & 0.867 & 0.567 & 0.815 \\
\hline & PEI4 & 0.754 & & & & \\
\hline & PEI5 & 0.793 & & & & \\
\hline \multirow{7}{*}{$\begin{array}{l}\text { Green } \\
\text { Purchase } \\
\text { Intention } \\
\text { (GPI) }\end{array}$} & GPI1 & 0.796 & & & & \\
\hline & GPI2 & 0.824 & & & & \\
\hline & GPI3 & 0.849 & & & & \\
\hline & GPI4 & 0.716 & 0.802 & 0.897 & 0.795 & 0.870 \\
\hline & GPI5 & Deleted & & & & \\
\hline & GPI6 & 0.735 & & & & \\
\hline & GPI7 & 0.753 & & & & \\
\hline
\end{tabular}

*Notes: EC1, EC4, PMO5, and GPI5 were deleted since factor loadings less than 0.5 . 
In addition, the discriminant validity of the constructs was tested by applying the Fornell-Larcker (1981) criterion and Heterotrait-Monotrait Ratio (HTMT) estimates. The square root of the AVE value of a variable should be higher than its highest correlation with every other model variable (Hair et al., 2014). As is evident from Table 2, the square root of each AVE construct exceeds its highest correlation with all the other constructs. Therefore, discriminant validity was attained.

Table 2: Fornell-Larcker Correlation Matrix

\begin{tabular}{ccccccccccc}
\hline & EA & EC & SN & PMO & PBC & ATT & PEV & PEI & GPI & $\begin{array}{c}\text { Discriminant } \\
\text { Validity }\end{array}$ \\
\hline EA & $\mathbf{0 . 8 7 6}$ & & & & & & & & & Yes \\
EC & 0.797 & $\mathbf{0 . 8 4 3}$ & & & & & & & Yes \\
SN & 0.715 & 0.671 & $\mathbf{0 . 8 0 5}$ & & & & & & Yes \\
PMO & 0.640 & 0.720 & 0.695 & $\mathbf{0 . 8 5 4}$ & & & & & & Yes \\
PBC & 0.662 & 0.753 & 0.724 & 0.839 & $\mathbf{0 . 8 7 1}$ & & & & Yes \\
ATT & 0.707 & 0.739 & 0.764 & 0.610 & 0.729 & $\mathbf{0 . 8 7 3}$ & & & & Yes \\
PEV & 0.719 & 0.747 & 0.668 & 0.708 & 0.698 & 0.759 & $\mathbf{0 . 7 7 5}$ & & & Yes \\
PEI & 0.621 & 0.632 & 0.751 & 0.679 & 0.720 & 0.724 & 0.697 & $\mathbf{0 . 7 5 3}$ & Yes \\
GPI & 0.503 & 0.557 & 0.525 & 0.517 & 0.614 & 0.531 & 0.661 & 0.711 & $\mathbf{0 . 8 9 1}$ & Yes \\
\hline
\end{tabular}

*Note: Diagonal-bold values are the Square root of AVE.

Likewise, the HTMT which is compatible with the de-attenuated construct score, is a measure of the correlation between the constructs (Table 3). This study finds no discriminant validity problem (Henseler et al., 2015) as all indicators of HTMT did not exceed the threshold value of 0.9 . In general, the study indicates that the reliability and validity of the data are adequate.

Table 3: Heterotrait-Monotrait Ratio (HTMT)

\begin{tabular}{cccccccccc}
\hline & EA & EC & SN & PMO & PBC & ATT & PEV & PEI & GPI \\
\hline EA & - & & & & & & & & \\
EC & 0.897 & - & & & & & & & \\
SN & 0.833 & 0.871 & - & & & & & & \\
PMO & 0.800 & 0.814 & 0.895 & - & & & & & \\
PBC & 0.862 & 0.851 & 0.781 & 0.829 & - & & & & \\
ATT & 0.807 & 0.835 & 0.864 & 0.833 & 0.769 & - & & & \\
PEV & 0.873 & 0.874 & 0.860 & 0.810 & 0.795 & 0.749 & - & & \\
PEI & 0.725 & 0.728 & 0.827 & 0.779 & 0.820 & 0.764 & 0.894 & - & \\
GPI & 0.896 & 0.767 & 0.803 & 0.731 & 0.714 & 0.841 & 0.861 & 0.846 & - \\
\hline
\end{tabular}

\section{Structural Model and Hypotheses Testing}

To test the direct effects identified in the hypotheses, Smart PLS version 3.2.8 was employed to analyse the collected data. To examine the relationship between constructs, the structural model was tested through the bootstrapping resampling technique. Following Hair et al. (2014), 5,000 bootstrapping sub-samples were created. Table 4 shows the analysis of the path coefficient for all hypotheses. 
Table 4: Evaluation of Structural Model and Hypothesis Testing

\begin{tabular}{|c|c|c|c|c|c|}
\hline Нypo. & Paths & Standardize Estimate & T-value & P-value & Results \\
\hline $\mathrm{H} 1$ & EA -> EC & 0.549 & 31.455 & $* * *$ & Supported \\
\hline $\mathrm{H} 2 \mathrm{a}$ & $\mathrm{EC}->\mathrm{SN}$ & 0.145 & 9.190 & $* * *$ & \\
\hline $\mathrm{H} 2 \mathrm{~b}$ & EC $->$ PMO & 0.315 & 13.215 & $* * *$ & Supported \\
\hline $\mathrm{H} 2 \mathrm{c}$ & $\mathrm{EC}->\mathrm{PBC}$ & 0.218 & 11.75 & $* * *$ & \\
\hline $\mathrm{H} 3 \mathrm{a}$ & EA $->$ SN & 0.573 & 37.6303 & $* * *$ & \\
\hline $\mathrm{H} 3 \mathrm{~b}$ & EA $->$ PMO & 0.206 & 10.236 & $* * *$ & Supported \\
\hline $\mathrm{H} 3 \mathrm{c}$ & EA $->$ PBC & 0.478 & 32.266 & $* * *$ & \\
\hline $\mathrm{H} 4 \mathrm{a}$ & SN $\rightarrow$ ATT & 0.208 & 8.171 & $* * *$ & Supported \\
\hline \multirow{2}{*}{$\mathrm{H} 4 \mathrm{~b}$} & $\mathrm{SN}->\mathrm{PEV}$ & 0.353 & 11.955 & $* * *$ & \multirow{2}{*}{ Supported } \\
\hline & $\mathrm{SN}->\mathrm{PEI}$ & 0.389 & 13.698 & $* * *$ & \\
\hline $\mathrm{H} 5 \mathrm{a}$ & PMO $->$ ATT & -0.022 & 1.024 & - & Not Supported \\
\hline \multirow{2}{*}{$\mathrm{H} 5 \mathrm{~b}$} & PMO -> PEV & 0.310 & 12.213 & $* * *$ & \multirow{2}{*}{ Supported } \\
\hline & PMO -> PEI & 0.090 & 4.025 & $* *$ & \\
\hline H6a & PBC $->$ ATT & 0.185 & 6.165 & $* * *$ & Supported \\
\hline \multirow{2}{*}{$\mathrm{H} 6 \mathrm{~b}$} & PBC -> PEV & 0.071 & 2.717 & $* *$ & \multirow{2}{*}{ Supported } \\
\hline & PBC -> PEI & 0.242 & 9.346 & $* * *$ & \\
\hline \multirow{2}{*}{$\mathrm{H} 7$} & PEV $->$ ATT & 0.088 & 4.588 & $* *$ & \multirow{2}{*}{ Supported } \\
\hline & PEI $->$ ATT & 0.326 & 14.157 & $* * *$ & \\
\hline \multirow[b]{2}{*}{$\mathrm{H} 8$} & PEV -> GPI & 0.540 & 25.291 & $* * *$ & \multirow{2}{*}{ Supported } \\
\hline & PEI -> GPI & 0.229 & 10.237 & $* * *$ & \\
\hline H9 & ATT $->$ GPI & 0.124 & 5.809 & $* * *$ & Supported \\
\hline
\end{tabular}

\section{Testing of Direct Effects}

The results revealed that EA has a significant and positive influence on EC $(\beta=0.549$; $t=31.455)$, SN $(\beta=0.573 ; t=37.63)$, PMO $(\beta=0.206 ; t=10.236)$ and $\mathrm{PBC}(\beta=0.478$; $t=32.266$ ). Therefore, $\mathrm{H} 1, \mathrm{H} 3 \mathrm{a}, \mathrm{H} 3 \mathrm{~b}$, and $\mathrm{H} 3 \mathrm{c}$ are supported. The findings also indicate that the relevant variables have a significant influence on environmental concern, including SN $(\beta=0.145 ; t=9.19), \operatorname{PMO}(\beta=0.315 ; t=13.215)$, and $\operatorname{PBC}(\beta=0.218$; $t=11.75$ ). Therefore, $\mathrm{H} 2 \mathrm{a}, \mathrm{H} 2 \mathrm{~b}$, and $\mathrm{H} 2 \mathrm{c}$ are supported. Concerning the relationship between $\mathrm{SN}$, attitude, and customer values, the empirical results indicate that $\mathrm{SN}$ has a significant and positive influence on ATT ( $\beta=0.208 ; t=8.171)$, perceived environmental value $(\beta=0.353 ; t=11.955)$, and perceived environmental image $(\beta=0.389 ; t=13.698)$. Therefore, hypotheses $\mathrm{H} 4 \mathrm{a}$ and $\mathrm{H} 4 \mathrm{~b}$ are supported. The results of this study are in agreement with those of previous studies (Shin et al., 2020). Besides, the empirical results indicate that $\mathrm{PMO}$ has a significant and positive influence on GCV, including perceived environmental value $(\beta=0.310 ; t=12.213)$ and perceived environmental image $(\beta=0.090 ; t=4.025)$. However, the effect of PMO $(\beta=-0.022 ; t=1.024)$ on ATT is not significant. Hence, H5a is not supported, while H5b is supported.

For the influence of $\mathrm{PBC}$, the empirical results indicate that $\mathrm{PBC}$ has a significant and positive influence on ATT $(\beta=0.185 ; t=6.165)$ and perceived environmental image $(\beta=0.242 ; t=9.346)$. The influence of $\operatorname{PBC}(\beta=0.071 ; t=2.717)$ on perceived environmental value is significant but negative. Therefore, H6a is supported, and H6b is partially supported. Besides, the empirical results reveal that perceived environmental value has a significant and positive influence on ATT $(\beta=0.088$; $t=4.588$ ). Furthermore, perceived environmental value has a significant and positive 
influence on GPI ( $\beta=0.540 ; t=25.291)$. Perceived environmental image has a significant and positive influence on ATT $(\beta=0.326 ; t=14.157)$. The influence of perceived environmental image on GPI is significant and positive $(\beta=0.229 ; t=10.237)$. Thus, $\mathrm{H} 7$ and $\mathrm{H} 8$ are supported. Furthermore, the empirical results showed that ATT has a significant and positive relationship with GPI $(\beta=0.124 ; t=5.809)$. Therefore, H9 is supported.

\section{Testing of Mediating Effects}

Table 5 presents the results for the direct and indirect effects that emerge from the tests of the significance of the mediator constructs. EC transmitted its effect on ATT and GCV via SN (indirect effects of $\beta=0.109$ and $\beta=0.065$, respectively; $p<0.05$ ), which indicates that SN mediates the relationship between EC and ATT and the relationship between EC and GCV. EC transmitted its effect on ATT and GCV via SN (indirect effects of $\beta=0.043$ and $\beta=0.115$, respectively; $p<0.05$ ). Therefore, SN mediates the relationship between EA and ATT and the relationship between EA and GCV. As far as the mediating effects of PMO are concerned, EC transmits its effect on GCV via PMO (indirect effect of $\beta=0.038, p<0.05$ ), which indicates that PMO mediates the relationship between EC and GCV. Moreover, EA transmits its effect on GCV via PMO (indirect effect of $\beta=0.053, p<0.05$ ), which indicates that PMO mediates the relationship between EA and GCV. Regarding the mediating effects of PBC, the results indicate that EC conveyed its effect on ATT and GCV via PBC (indirect effects of $\beta=0.068$ and $\beta=0.083$, respectively; $p<0.05$ ), which indicates that PBC mediates the relationship between EC and ATT and the relationship between EC and GCV. EA transmitted its effect on ATT via PBC (indirect effect of $\beta=0.076, \mathrm{p}<0.05$ ) which indicates that PBC mediates the relationship between EA and ATT. In respect of the mediating effects of ATT, the results show that SN affects GPI via ATT (indirect effect of $\beta=0.082, p<0.05$ ), which indicates that ATT mediates the relationship between SN and GPI. The results also showed that PBC conveyed its effect on GPI via ATT (indirect effect of $\beta=0.169, p<0.05$ ), which indicates that ATT mediates the relationship between PBC and GPI.

Table 5: The Results of Direct and Indirect Effects

\begin{tabular}{|c|c|c|c|c|c|}
\hline Paths & $\begin{array}{c}\text { Direct Effect } \\
\text { (t-value) }\end{array}$ & $\begin{array}{l}95 \% \\
\text { CI }\end{array}$ & $\begin{array}{c}\text { Indirect effect } \\
\text { (t-value) }\end{array}$ & $\begin{array}{l}95 \% \\
\text { CI }\end{array}$ & $\begin{array}{c}\text { Type of } \\
\text { mediation }\end{array}$ \\
\hline \multicolumn{6}{|l|}{ Mediator: SN } \\
\hline $\mathrm{EC} \rightarrow \mathrm{SN} \rightarrow \mathrm{ATT}$ & $\begin{array}{l}0.027^{\mathrm{ns}} \\
(0.365)\end{array}$ & $\begin{array}{c}-0.017 \\
0.128\end{array}$ & $\begin{array}{l}0.109^{*} \\
(3.257)\end{array}$ & $\begin{array}{l}0.033 \\
0.070\end{array}$ & Full mediation \\
\hline $\mathrm{EC} \rightarrow \mathrm{SN} \rightarrow \mathrm{GCV}$ & $\begin{array}{l}0.064^{\text {ns }} \\
(0.765)\end{array}$ & $\begin{array}{c}-0.041 \\
0.328\end{array}$ & $\begin{array}{l}0.065^{*} \\
(3.162)\end{array}$ & $\begin{array}{l}0.053 \\
0.170\end{array}$ & Full mediation \\
\hline $\mathrm{EA} \rightarrow \mathrm{SN} \rightarrow \mathrm{ATT}$ & $\begin{array}{l}0.051^{\mathrm{ns}} \\
(0.786)\end{array}$ & $\begin{array}{c}-0.075 \\
0.186\end{array}$ & $\begin{array}{l}0.043^{*} \\
(2.010)\end{array}$ & $\begin{array}{l}0.010 \\
0.095\end{array}$ & Full mediation \\
\hline $\mathrm{EA} \rightarrow \mathrm{SN} \rightarrow \mathrm{GCV}$ & $\begin{array}{l}0.043^{\text {ns }} \\
(0.562)\end{array}$ & $\begin{array}{c}-0.031 \\
0.232\end{array}$ & $\begin{array}{l}0.115^{*} \\
(3.580)\end{array}$ & $\begin{array}{l}0.093 \\
0.073\end{array}$ & Full mediation \\
\hline \multicolumn{6}{|l|}{ Mediator: PMO } \\
\hline $\mathrm{EC} \rightarrow \mathrm{PMO} \rightarrow \mathrm{ATT}$ & $\begin{array}{l}0.027 * \\
(1.254)\end{array}$ & $\begin{array}{c}-0.038 \\
0.279\end{array}$ & $\begin{array}{l}-0.013^{\mathrm{ns}} \\
(0.538)\end{array}$ & $\begin{array}{c}-0.017 \\
0.053\end{array}$ & Non-mediation \\
\hline $\mathrm{EC} \rightarrow \mathrm{PMO} \rightarrow \mathrm{GCV}$ & $\begin{array}{l}0.072^{\text {ns }} \\
(0.917)\end{array}$ & $\begin{array}{c}0.009 \\
0.084\end{array}$ & $\begin{array}{l}0.038^{*} \\
(2.044)\end{array}$ & $\begin{array}{l}0.009 \\
0.084\end{array}$ & Full mediation \\
\hline $\mathrm{EA} \rightarrow \mathrm{PMO} \rightarrow \mathrm{ATT}$ & $0.133^{*}$ & 0.018 & $0.033^{\text {ns }}$ & 0.007 & Non-mediation \\
\hline
\end{tabular}




\begin{tabular}{|c|c|c|c|c|c|}
\hline $\mathrm{EA} \rightarrow \mathrm{PMO} \rightarrow \mathrm{GCV}$ & $\begin{array}{c}(2.254) \\
0.042^{\text {ns }} \\
(0.686)\end{array}$ & $\begin{array}{c}0.249 \\
-0.055 \\
0.196\end{array}$ & $\begin{array}{c}(1.938) \\
0.053 * \\
(2.105)\end{array}$ & $\begin{array}{c}0.073 \\
0.030 \\
0.075\end{array}$ & Full mediation \\
\hline \multicolumn{6}{|l|}{ Mediator: PBC } \\
\hline $\mathrm{EC} \rightarrow \mathrm{PBC} \rightarrow \mathrm{ATT}$ & $\begin{array}{l}0.058^{\mathrm{ns}} \\
(0.711)\end{array}$ & $\begin{array}{l}0.013 \\
0.074\end{array}$ & $\begin{array}{l}0.068^{*} \\
(2.144)\end{array}$ & $\begin{array}{l}0.059 \\
0.074\end{array}$ & Full mediation \\
\hline $\mathrm{EC} \rightarrow \mathrm{PBC} \rightarrow \mathrm{GCV}$ & $\begin{array}{l}0.023^{\text {ns }} \\
(0.436)\end{array}$ & $\begin{array}{l}-0.025 \\
0.123\end{array}$ & $\begin{array}{l}0.083^{*} \\
(2.410)\end{array}$ & $\begin{array}{l}0.110 \\
0.105\end{array}$ & Full mediation \\
\hline $\mathrm{EA} \rightarrow \mathrm{PBC} \rightarrow \mathrm{ATT}$ & $\begin{array}{l}0.049^{\text {ns }} \\
(0.631)\end{array}$ & $\begin{array}{c}-0.038 \\
0.304\end{array}$ & $\begin{array}{l}0.076^{*} \\
(2.301)\end{array}$ & $\begin{array}{l}0.050 \\
0.085\end{array}$ & Full mediation \\
\hline $\mathrm{EA} \rightarrow \mathrm{PBC} \rightarrow \mathrm{GCV}$ & $\begin{array}{l}0.055^{\text {ns }} \\
(1.483)\end{array}$ & $\begin{array}{l}-0.021 \\
0.128\end{array}$ & $\begin{array}{l}-0.002^{\text {ns }} \\
(0.415)\end{array}$ & $\begin{array}{l}-0.016 \\
0.009\end{array}$ & Non-mediation \\
\hline \multicolumn{6}{|l|}{ Mediator: ATT } \\
\hline $\mathrm{SN} \rightarrow \mathrm{ATT} \rightarrow \mathrm{GPI}$ & $\begin{array}{l}0.063^{\text {ns }} \\
(0.667)\end{array}$ & $\begin{array}{l}-0.081 \\
0.402\end{array}$ & $\begin{array}{l}0.082 * \\
(2.205)\end{array}$ & $\begin{array}{l}0.041 \\
0.055\end{array}$ & Full mediation \\
\hline $\mathrm{PMO} \rightarrow \mathrm{ATT} \rightarrow \mathrm{GPI}$ & $\begin{array}{l}0.033^{\text {ns }} \\
(0.274)\end{array}$ & $\begin{array}{l}-0.018 \\
0.249\end{array}$ & $\begin{array}{c}-0.043^{\text {ns }} \\
(0.938)\end{array}$ & $\begin{array}{l}-0.017 \\
0.083\end{array}$ & Non-mediation \\
\hline $\mathrm{PBC} \rightarrow \mathrm{ATT} \rightarrow \mathrm{GPI}$ & $\begin{array}{l}0.071^{\mathrm{ns}} \\
(0.689)\end{array}$ & $\begin{array}{l}-0.064 \\
0.701\end{array}$ & $\begin{array}{l}0.169^{*} \\
(3.670)\end{array}$ & $\begin{array}{l}0.057 \\
0.178\end{array}$ & Full mediation \\
\hline $\mathrm{GCV} \rightarrow \mathrm{ATT} \rightarrow \mathrm{GPI}$ & $\begin{array}{l}0.126^{*} \\
(2.037)\end{array}$ & $\begin{array}{l}0.006 \\
0.167\end{array}$ & $\begin{array}{l}0.031^{\mathrm{ns}} \\
(0.878)\end{array}$ & $\begin{array}{c}-0.037 \\
0.104\end{array}$ & Non-mediation \\
\hline \multicolumn{6}{|l|}{ Mediator: GCV } \\
\hline $\mathrm{SN} \rightarrow \mathrm{GCV} \rightarrow \mathrm{GPI}$ & $\begin{array}{l}0.103^{*} \\
(2.010)\end{array}$ & $\begin{array}{l}0.004 \\
0.132\end{array}$ & $\begin{array}{l}0.021^{\mathrm{ns}} \\
(0.648)\end{array}$ & $\begin{array}{l}-0.025 \\
0.105\end{array}$ & Non-mediation \\
\hline $\mathrm{PMO} \rightarrow \mathrm{GCV} \rightarrow \mathrm{GPI}$ & $\begin{array}{l}0.133^{*} \\
(2.106)\end{array}$ & $\begin{array}{l}0.024 \\
0.152\end{array}$ & $\begin{array}{l}0.037^{\text {ns }} \\
(0.703)\end{array}$ & $\begin{array}{l}-0.032 \\
0.163\end{array}$ & Non-mediation \\
\hline $\mathrm{PBC} \rightarrow \mathrm{GCV} \rightarrow \mathrm{GPI}$ & $\begin{array}{l}0.215^{*} \\
(2.317)\end{array}$ & $\begin{array}{l}0.036 \\
0.173\end{array}$ & $\begin{array}{l}0.061^{\mathrm{ns}} \\
(0.795)\end{array}$ & $\begin{array}{l}-0.051 \\
0.148\end{array}$ & Non-mediation \\
\hline $\mathrm{SN} \rightarrow \mathrm{GCV} \rightarrow \mathrm{ATT}$ & $\begin{array}{l}0.146^{*} \\
(2.026)\end{array}$ & $\begin{array}{l}0.020 \\
0.300\end{array}$ & $\begin{array}{l}0.017^{*} \\
(1.063)\end{array}$ & $\begin{array}{c}-0.008 \\
0.079\end{array}$ & Non-mediation \\
\hline $\mathrm{PMO} \rightarrow \mathrm{GCV} \rightarrow \mathrm{ATT}$ & $\begin{array}{c}0.341 * * * \\
(3.954)\end{array}$ & $\begin{array}{c}0.166 \\
0.505\end{array}$ & $\begin{array}{l}0.028^{*} \\
(1.047)\end{array}$ & $\begin{array}{c}-0.014 \\
0.107\end{array}$ & Non-mediation \\
\hline $\mathrm{PBC} \rightarrow \mathrm{GCV} \rightarrow \mathrm{ATT}$ & $\begin{array}{l}0.140 * * \\
(3.176)\end{array}$ & $\begin{array}{l}0.052 \\
0.223\end{array}$ & $\begin{array}{l}-0.003^{\mathrm{ns}} \\
(0.409)\end{array}$ & $\begin{array}{c}-0.018 \\
0.009\end{array}$ & Non-mediation \\
\hline
\end{tabular}

*Note: $n s=$ non-significant; ${ }^{* * *} p<0.01,{ }^{* *} p<0.01,{ }^{*} p<0.05$; CI: confidence interval.

\section{Academic and Practical Implications}

\section{Academic Implications}

Three significant academic contributions are made by this study. To begin, the VBN and TPB models have been expanded and used in research on customer purchase intentions. The findings indicate that the integration of TPB, value, and environmental concern is appropriate and can adequately explain GPI. Second, the VBN theory was used to explain the effect of EA on EC, which aided SN, PBC, and PMO. TPB was used to explain the impact of SN, PBC, and PMO on GPI via attitude. Finally, theory of moral obligation can adopt to explain the role of customer value in mediating the influence of SN, PBC, and PMO on GPI. Because previous studies omitted various factors and perspectives relevant to GPI, the research framework of this study is comprehensive and novel, with academic support from a variety of perspectives. 


\section{Managerial Implications}

The study has some essential insights for managers. It can guide decision-makers and campaign managers in identifying the key predictors of GBI. Marketers should recognize the factors and challenges of green purchasing. To begin, marketers should consider the impact of $\mathrm{EC}$ and $\mathrm{EA}$ on $\mathrm{SN}, \mathrm{PBC}$, and PMO. It is critical to promote customer concerns about subjective norms, moral obligation, and behaviour control in order to facilitate GPI. Firms must engage in various management and market environmental-related activities to stimulate environmental concerns and awareness, which in turn facilitates moral obligation, attitude, and GPI. Second, the mediation roles of the SN, PBC, and PMO are critical for the promotion of attitude and customer values. Consumers probably participate in eco-friendly behaviours depending on existing norms and ethical standards. To enhance customer attitude, managers can enhance consumers' EA and EC by presenting environmental issues through multiple channels of communication, such as news media (e.g., TV) and social media (e.g., Facebook, Twitter, LinkedIn). It is important that when EA and EC can be activated, then the mediation roles for the influence of SN and $\mathrm{PBC}$ on attitude and the influence of PMO on customer values can be performed. Thus, SN, PBC, and PMO from the customer are the main issues that marketers should pay the highest attention to promote green purchasing. In particular, because a large portion of this study's sample consists of young people, and the young are the focus of companies' activities. They are also more knowledgeable about environmental issues. They can also have a significant influence on the purchasing decisions of family members. Furthermore, because these young consumers are very familiar with social media platforms, managers should incorporate environmental education into the national education system to increase GPI. Furthermore, the emotional and rational appeal of green marketing can be emphasized to highlight specific environmental or social problems. Customers can be educated about the benefits of green purchases in this manner.

\section{Limitations and Future Research Directions}

The study's findings must be interpreted in light of its limitations. First, the study's respondents were contacted via e-mail. Similarities in the respondents' environments, cultures, and other characteristics are likely to have been significant. Future research could use a larger sample from different countries and cultures, or it could concentrate on a specific group of customers who buy a specific brand of green products. Second, this study created a comprehensive research model that includes both the causes and consequences of green purchasing. It is, however, impossible to guarantee that other variables are unimportant. It is encouraged to identify additional relevant factors. Lastly, our sample had a higher percentage of younger respondents than older respondents, which may have resulted in a slight bias in our research findings. It is critical for future studies to collect data from various cities in Cambodia, and future studies can increase the sample size to ensure the generalizability of research findings.

\section{Practical Implications for Asian Business}

Several practical implications for Asian businesses can be drawn from the results of this study. The current research integrated different theories to develop influential 
antecedents and mediators for GPI. The findings suggest that Asian marketers should try to attract consumers' attention using rational and emotional green appeals, as these could help influence consumers' attitudes, values, and intentions towards the purchase of a green product. Through attractive green marketing strategies, the companies can indirectly train and enhance consumer awareness and concern about the impact of green products on protecting the earth and sustainability development. Therefore, by improving the green marketing advertisement, attitude towards the green products and green purchasing intention will be promoted. Attitude towards purchasing green products played a mediator to purchase intention; consumers who are aware of the environment and have a positive attitude can make favorable adjustments towards GPI. Additionally, environmental concern is among the most effective variables in determining GPI, suggesting that governments, private sectors, entrepreneurs, and policymakers in Asian countries should develop public interventions showcasing how the consumption of green products could help in reducing negative environmental impact. Doing so could help increase the consumer's purchase intention for green products, which further facilitates green behaviour performance. To increase consumers' perceived value of green products, marketers must highlight their function and create a strong environmental image and environmental value for customers. Marketers, for example, can use emotional appeals, fear appeals, humor appeals, or color psychology to directly affect the customer's emotion and behavior intention.

The findings of this study also have several implications for Asian policymakers, especially in Cambodia. The outcomes suggested that subjective norms and perceived behavioural control play the role of mediators for the relationship between environmental issues (including environment concern and environment awareness) and the Cambodian customer's attitude and value towards the green product. Perceived moral obligation serve the role of mediator for the relationship between environmental issues and green customer value. Based on these investigations, the managers and marketers should target the youth through their advertising campaigns, educational activities such as special workshops to enhance the subjective norms, behavioural control, moral obligation, and offer special discounts and free services. Green marketing is progressing day by day in Cambodia, so marketers need to create convincing advertisement campaigns for the green products and manufacturer firms also need to produce a trustworthy green product so that a strong positive attitude can be built. Furthermore, marketers and government, and employees are required to create awareness regarding the benefits of using green products, knowledge about green labels so that consumers can easily recognize and consume green products. Besides this, the government should facilitate the green purchase tax deduction and legislation incentives. Moreover, the government should formulate policies that could encourage the manufacturer to produce green products because these products create a sustainable environment for the state. Consumers will have a more positive attitude towards green products when they are worried about the environment and sustainable life. As such, the Asian government must focus on promoting the idea of environmental protection to improve the public's environmental concerns. In the same vein, Asian governments and the Cambodian government may focus on public communication or incorporate environmental issues into school education for moving the youth towards a green model of economic growth and sustainability. 


\section{References}

Aboelmaged, M. (2020), "E-waste recycling behaviour: an integration of recycling habits into the technology acceptance model and the theory of planned behaviour", Journal of Cleaner Production, 124182.

Ajzen, I. (1985), "From intentions to actions: A theory of planned behaviour" in Kuhl J. and Beckmann J. (Eds), Action Control, SSSP Springer Series in Social Psychology, Springer, Berlin, Heidelberg.

Ajzen, I. (1991), "The theory of planned behaviour", Organizational Behaviour and Human Decision Processes, vol. 50, no. 2, pp. 179-211.

Al-Gasawneh, J. and Al-Adamat, A. (2020), "The mediating role of e-word of mouth on the relationship between content marketing and GPI", Management Science Letters, vol. 10, no. 8, pp. 1701-1708.

Aman, A.L., Harun, A. and Hussein, Z. (2012), "The influence of environmental knowledge and concern on GPI the role of attitude as a mediating variable”, British Journal of Arts and Social Sciences, vol. 7, no. 2, pp. 145-167.

Amoako, G.K., Dzogbenuku, R.K. and Abubakari, A. (2020), "Do green knowledge and attitude influence the youth's green purchasing? Theory of planned behaviour", International Journal of Productivity and Performance Management.

Appolloni, A., Sun, H., Jia, F. and Li, X. (2014), "Green procurement in the private sector: a state-of-the-art review between 1996 and 2013", Journal of Cleaner Production, vol. 85, pp. 122-133.

Ari, E. and Y1lmaz, V. (2017), "Effects of environmental illiteracy and environmental awareness among middle school students on environmental behaviour", Environment, Development and Sustainability, vol. 19, no. 5, pp. 1779-1793.

Bandura, A. (2002), "Social cognitive theory in cultural context", Applied Psychology, vol. 51, no. 2, pp. 269-290.

Barbarossa, C. and Pelsmacker, P. (2016), "Positive and negative antecedents of purchasing eco-friendly products: A comparison between green and non-green consumers", Journal of Business Ethics, vol. 134, no. 2, pp. 229-247.

Barber, N.A., Bishop, M. and Gruen, T. (2014), "Who pays more (or less) for proenvironmental consumer goods? Using the auction method to assess actual willingness-to-pay", Journal of Environmental Psychology, vol. 40, pp. 218-227.

Beck, L. and Ajzen, I. (1991), "Predicting dishonest actions using the theory of planned behaviour", Journal of Research in Personality, vol. 25, no. 3, pp. 285-301.

Björklund, M. (2011), "Influence from the business environment on environmental purchasing- Drivers and hinders of purchasing green transportation services", Journal of Purchasing and Supply Management, vol. 17, no. 1, pp. 11-22.

Bockarjova, M., and Steg, L. (2014), "Can protection motivation theory predict proenvironmental behaviour? Explaining the adoption of electric vehicles in the Netherlands", Global Environmental Change, vol. 28, pp. 276-288.

Bray, J., Johns, N. and Kilburn, D. (2011), "An exploratory study into the factors impeding ethical consumption", Journal of Business Ethics, vol. 98, pp. 597-608.

Buschmann, S., Chen, M.F. and Hauer, G. (2020), "An integrated model of the theory of reasoned action and technology acceptance model to predict the consumers' intentions to adopt electric carsharing in Taiwan" in Planing, P., Müller, P., Dehdari P. and Bäumer T. (Eds), Innovations for Metropolitan Areas, Springer, Berlin, Heidelberg.

Carrete, L., Castaño, R., Felix, R., Centeno, E. and González, E. (2012), “Green 
consumer behaviour in an emerging economy: confusion, credibility, and compatibility", Journal of Consumer Marketing, vol. 29, no. 7, pp. 470-481.

Chan, R. (2001), "Determinants of Chinese consumers' green purchase behaviour", Psychology and Marketing, vol. 18, no. 4, pp. 389-413.

Chen, M. F. (2014), "An examination of the value-belief-norm theory model in predicting pro-environmental behaviour in Taiwan", Asian Journal of Social Psychology, vol. 18, no. 2, pp. 145-151.

Chen, M.F. (2016), "Extending the theory of planned behaviour model to explain people's energy savings and carbon reduction behavioural intentions to mitigate climate change in Taiwan-Moral obligation matters", Journal of Cleaner Production, vol. 112, pp. 1746-1753.

Choi, H., Jang, J. and Kandampully, J. (2015), "Application of the extended VBN theory to understand consumers' decisions about green hotels", International Journal of Hospitality Management, vol. 51, pp. 87-95.

Fishbein, M. and Ajzen, I. (2011), "Predicting and Changing Behaviour the Reasoned Action Approach" (1st Ed.), Psychology Press, New York.

Fornell, C. and Larcker, D.F. (1981), "Structural equation models with unobservable variables and measurement error: Algebra and statistics", Journal of Marketing Research, vol. 18, no. 3, pp. 382-388.

$\mathrm{Fu}$, B., Kurisu, K., Hanaki, K. and Che, Y. (2018), "Influential factors of public intention to improve the air quality in China", Journal of Cleaner Production.

Gallarza, M.G., Gil-Saura, I. and Holbrook, M.B. (2011), "The value of value: Further excursions on the meaning and role of customer value", Journal of Consumer Behaviour, vol. 10, no. 4, pp. 179-191.

Gershoff, A.D. and Frels, J.K. (2015), "What makes it green? The role of centrality of green attributes in evaluations of the greenness of products", Journal of Marketing, vol. 79, no. 1, pp. 97-110.

Gu, D., Jiang, J., Zhang, Y., Sun, Y., Jiang, W. and Du, X. (2020), "Concern for the future and saving the earth: When does ecological resource scarcity promote pro-environmental behaviour?", Journal of Environmental Psychology.

Hair, J.F., Sarstedt, M., Hopkins, L. and Kuppelwieser, V.G. (2014), "Partial least squares structural equation modeling (PLS-SEM)", European Business Review, vol. 26 , no. 2 , pp. 106-121.

Hamzah, M.I. and Tanwir, N.S. (2020), "Do pro-environmental factors lead to purchase intention of hybrid vehicles? The moderating effects of environmental knowledge", Journal of Cleaner Production, 123643.

Hänninen, N. and Karjaluoto, H. (2017), "Environmental values and customerperceived value in industrial supplier relationships", Journal of Cleaner Production, vol. 156, pp. 604- 613.

Henseler, J., Ringle, C.M. and Sarstedt, M. (2015), "A new criterion for assessing discriminant validity in variance-based structural equation modeling", Journal of the Academy of Marketing Science, vol. 43, no. 1, pp. 115-135.

Ishaswini, N. and Datta, S.K. (2011), "Pro-environmental concern influencing green buying: A study on Indian consumers", International Journal of Business and Management, vol. 6, no. 6, pp. 124-133.

Ivancevich, S.H., Ivancevich, D.M. and Elikai, F. (2010), "Accounting software selection and satisfaction", The CPA Journal, vol. 80, no. 1, p. 66.

Jaiswal, D. and Kant, R. (2018), "Green purchasing behaviour: A conceptual framework and empirical investigation of Indian consumers", Journal of Retailing and Consumer Services, vol. 41, pp. 60-69. 
Jiang, C., Rashid, R.M. and Wang, J. (2019), "Investigating the role of social presence dimensions and information support on consumers' trust and shopping intentions", Journal of Retailing and Consumer Services, vol. 51, pp. 263-270.

Joshi, Y. and Rahman, Z. (2015), "Factors affecting green purchase behaviour and future research directions", International Strategic Management Review, vol. 3, no. 1 , pp. 128-143.

Junquera, B., del Brío, J. Á. and Fernández, E. (2012), "Clients' involvement in environmental issues and organizational performance in businesses: an empirical analysis", Journal of Cleaner Production, vol. 37, pp. 288-298.

Kang, H., Hahn, M., Fortin, D.R., Hyun, Y.J. and Eom, Y. (2006), "Effects of PBC on the consumer usage intention of e-coupons", Psychology and Marketing, vol. 23, no. 10, pp. 841-864.

Kim, C., Galliers, R.D., Shin, N., Ryoo, J.H. and Kim, J. (2014), "Factors influencing Internet shopping value and customer repurchase intention", Electronic Commerce Research and Applications, vol. 11, no. 4, pp. 374-387.

Kim, E., Ham, S., Yang, I.S. and Choi, J.G. (2013), "The roles of attitude, subjective norm, and perceived behavioral control in the formation of consumers' behavioral intentions to read menu labels in the restaurant industry", International Journal of Hospitality Management, vol. 35, pp. 203-213.

Klöckner, C.A. (2013), "A comprehensive model of the psychology of environmental behaviour-A meta-analysis", Global Environmental Change, vol. 23, no. 5, pp. 1028-1038.

Kollmuss, A. and Agyeman, J. (2002), "Mind the gap: why do people act environmentally and what are the barriers to pro-environmental behaviour?", Environmental Education Research, vol. 8, no. 3, pp. 239-260.

Lee, Y.K., Kim, S., Kim, M.S. and Choi, J.G. (2014), "Antecedents and interrelationships of three types of pro-environmental behaviour", Journal of Business Research, vol. 67, no. 10, pp. 2097-2105.

Leonard, M., Graham, S. and Bonacum, D. (2004), "The human factor: the critical importance of effective teamwork and communication in providing safe care", BMJ Quality and Safety, vol. 13, no. 1, pp. i85-i90.

Li, M. and Cai, L.A. (2012), "The effects of personal values on travel motivation and behavioural intention", Journal of Travel Research, vol. 51, no. 4, pp. 473-487.

Liao, Y.K., Wu, W.Y. and Pham, T.T. (2020), "Examining the moderating effects of green marketing and green psychological benefits on customers' green attitude, value and purchase intention", Sustainability, vol. 12, p. 7461.

MacKenzie, S.B. and Podsakoff, P.M. (2012), "Common method bias in marketing: Causes, mechanisms, and procedural remedies", Journal of Retailing, vol. 88, no. 4, pp. 542-555.

Maichum, K., Parichatnon, S. and Peng, K.C. (2016), "Application of the extended theory of planned behaviour model to investigate purchase intention of green products among Thai consumers", Sustainability, vol. 8, no. 10, p. 1077.

Mäkiniemi, J.P. and Vainio, A. (2013), "Moral intensity and climate-friendly food choices", Appetite, vol. 66, pp. 54-61.

Michaelidou, N. and Hassan, L.M. (2010), "Modeling the factors affecting rural consumers' purchase of organic and free-range produce: A case study of consumers' from the Island of Arran in Scotland, UK", Food Policy, vol. 35, no. 2 , pp. $130-139$.

Moons, I. and De Pelsmacker, P. (2012), "Emotions as determinants of electric car usage intention", Journal of Marketing Management, vol. 28, no. 3-4, pp. 195 - 
237.

Morwitz, V.G. and Fitzsimons, G.J. (2004), "The mere-measurement effect: Why does measuring intentions change actual behaviour?", Journal of Consumer Psychology, vol. 14, no. 1, pp. 64-74.

Mostafa, M.M. (2007), "A hierarchical analysis of the green consciousness of the Egyptian consumer", Psychological Marketing, vol. 24, no. 5, pp. 445-473.

Nimri, R., Patiar, A. and Jin, X. (2020), "The determinants of consumers' intention of purchasing green hotel accommodation: Extending the theory of planned behaviour", Journal of Hospitality and Tourism Management, vol. 45, pp. 535543.

Nuttavuthisit, K. and Thøgersen, J. (2017), "The importance of consumer trust for the emergence of a market for green products: The case of organic food", Journal of Business Ethics, vol. 140, pp. 323-337.

Oskamp, S., Harrington, M.J., Edwards, T.C., Sherwood, D.L., Okuda, S.M. and Swanson, D.C. (1991), "Factors influencing household recycling behaviour", Environment and Behaviour, vol. 23, no. 4, pp. 494-519.

Patterson, P.G. and Spreng, R.A. (1997), "Modelling the relationship between perceived value, satisfaction and repurchase intentions in a business-tobusiness, services context: an empirical examination", International Journal of Service Industry Management, vol. 8, no. 5, pp. 414-434.

Paul, J., Modi, A. and Patel, J. (2016), "Predicting green product consumption using theory of planned behaviour and reasoned action", Journal of Retailing and Consumer Services, vol. 29, pp. 123-134.

Podsakoff, P.M., MacKenzie, S.B., Lee, J.Y. and Podsakoff, N.P. (2003), "Common method biases in behavioral research: a critical review of the literature and recommended remedies", Journal of Applied Psychology, vol. 88, no. 5, p. 879.

Prakash, G. and Pathak, P. (2017), "Intention to buy eco-friendly packaged products among young consumers of India: A study on developing nation", Journal of Cleaner Production, vol. 141, pp. 385-393.

Ramayah, T., Lee, J.W.C. and Mohamad, O. (2012), "Green product purchase intention: Some insights from a developing country", Resources, Conservation and Recycling, vol. 54, no. 12, pp. 1419-1427.

Reuter, C., Goebel, P. and Foerstl, K., (2012), "The impact of stakeholder orientation on sustainability and cost prevalence in supplier selection decisions", Journal of Purchasing and Supply Management, vol. 18, no. 4, pp. 270-281.

Rodríguez-Barreiro, L.M., Fernández-Manzanal, R., Serra, L.M., Carrasquer, J., Murillo, M.B., Morales, M.J., ... and Valle, J. del. (2013), “Approach to a causal model between attitudes and environmental behaviour. A graduate case study", Journal of Cleaner Production, vol. 48, pp. 116-125.

Ross, D. and Hahn, R. (2019), "Understanding collaborative consumption: An extension of the theory of planned behaviour with value-based personal norms", Journal of Business Ethics, vol. 158, pp. 679-697.

Scott, L. and Vigar-Ellis, D. (2014), "Consumer understanding, perceptions and behaviours with regard to environmentally friendly packaging in a developing nation", International Journal of Consumer Studies, vol. 38, no. 6, pp. 642-649.

Shaw, D., McMaster, R. and Newholm, T. (2015), "Care and commitment in ethical consumption: An exploration of the "attitude-behaviour gap", Journal of Business Ethics, vol. 136, no. 2, pp. 251-265.

Shin, Y.H., Jung, S.E., Im, J. and Severt, K. (2020), “Applying an extended theory of planned behaviour to examine state-branded food product purchase behaviour: 
The moderating effect of gender", Journal of Foodservice Business Research, vol. 23 , no. 4 , pp. 358-375.

Spielmann, N. (2020), "Green is the new white: How virtue motivates green product purchase, Journal of Business Ethics.

Sreen, N., Purbey, S. and Sadarangani, P. (2018), "Impact of culture, behaviour and gender on green purchase intention", Journal of Retailing and Consumer Services, vol. 41, pp. 177-189.

Stern, P.C. (2000), "New environmental theories: toward a coherent theory of environmentally significant behaviour", Journal of Social Issues, vol. 56, no. 3, pp. 407-424.

Taufique, K.M.R., Siwar, C., Chamhuri, N. and Sarah, F.H. (2016), "Integrating general environmental knowledge and eco-label knowledge in understanding ecologically conscious consumer behaviour", Procedia Economics and Finance, vol. 37, pp. 39-45.

Vaishali, S. and Anuradha, J. (2020), "The role of SNs in purchase behaviour of green FMCG products", International Journal of Technology Transfer and Commercialisation, vol. 17, no. (2-3).

Varah, F., Mahongnao, M., Pani, B. and Khamrang, S. (2020), "Exploring young consumers' intention toward green products: applying an extended theory of planned behavior", Environment, Development and Sustainability.

Wang, S., Fan, J., Zhao, D., Yang, S. and Fu, Y. (2016), "Predicting consumers' intention to adopt hybrid electric vehicles: using an extended version of the theory of planned behaviour model", Transportation, vol. 43, no. 1, pp. 123143.

Wheeler, M., Sharp, A. and Nenycz-Thiel, M. (2013), "The effect of "green" messages on brand purchase and brand rejection", Australasian Marketing Journal, vol. 21, no. 2, pp. 105-110.

White, K., Habib, R. and Hardisty, D.J. (2019), "How to shift consumer behaviours to be more sustainable: A literature review and guiding framework", Journal of Marketing, vol. 83, no.3, pp. 22-49.

Witek, L. (2019), "Attitude-behaviour gap among Polish consumers regarding green purchases", Visegrad Journal on Bioeconomy and Sustainable Development, vol. 8 , no. 1, pp. 31-36.

Yang, M.X., Tang, X., Cheung, M.L. and Zhang, Y. (2020), “An institutional perspective on consumers' environmental awareness and pro-environmental behavioural intention: Evidence from 39 countries", Business Strategy and the Environment.

Yue, B., Sheng, G., She, S. and Xu, J. (2020), "Impact of consumer environmental responsibility on green consumption behaviour in China: The role of environmental concern and price sensitivity", Sustainability, vol. 12, p. 2074.

Zeinab, Z. (2021), "The effects of consumer attitude on green purchase intention: A metaanalytic path analysis", Journal of Business Research, vol. 132, pp. 732-743.

Zikmund, G.W. and Babin, B.J. (2010), Essentials of marketing research, 4th ed., South Western Cengage Learning, Mason, $\mathrm{OH}$. 